\title{
Austrian diplomacy in a changing global and European context: Between innovation, adaptation and resilience
}

\author{
Heidi Maurer ${ }^{1, *}$ \\ 1 Faculty of Arts and Social Sciences, Maastricht University, Maastricht, The Netherlands \\ * E-Mail: h.maurer@maastrichtuniversity.nl
}

\begin{abstract}
Twenty years after Austria joining the EU, this contribution investigates how Austrian diplomacy has been adjusting to the changing European demands and opportunities next to global and domestic pressures for adaptation.

Austrian diplomatic adaptation has predominantly been reactive. EU membership and EU sanctions pushed Austrian diplomats to re-adjust their role conceptions. On a more structural level, Austrian diplomacy followed global trends, while domestic budget cuts and lack of strategic reorientation acted as constrains. Also the introduction of the European External Action Service triggered a rather reactive response to top down Europeanization: the increased European diplomatic coordination attempts since 2009 are considered additional tools rather than a substitute for Austrian diplomacy.
\end{abstract}

\section{Keywords}

Austria, diplomacy, EU foreign policy, European External Action Service, EU delegations

\section{Österreichische Diplomatie im Kontext eines veränderten globalen und Europäischen Umfeldes: zwischen Innovation, Adaptierung und Widerstand}

\section{Zusammenfassung}

20 Jahre nach Österreichs EU-Beitritt untersucht dieser Beitrag die Europäisierung österreichischer Diplomatie in ihrer Wechselwirkung mit globalen Trends und nationalen Herausforderungen. Dieser Beitrag beurteilt die Anpassung österreichischer Diplomatie im globalen, europäischen und nationalen Kontext über Zeit.

Der Wandel österreichischer Diplomatie ist vorwiegend als reaktiv zu klassifizieren. Diplomaten haben ihr Rollenverständnis im Zuge von EU Mitgliedschaft und EU Sanktionen angepasst, während auf struktureller Ebene die österreichische Diplomatie globalen Trends folgt. Diese Neuorientierungen sind allerdings stark beschränkt durch andauernd nationale Budgetkürzungen und den Mangel einer strategischen Neuausrichtung. Auch die Einführung des Europäischen Auswärtigen Dienstes wurde als top-down Europäisierung akzeptiert: die verstärkt europäischen diplomatischen Koordinierungsversuche seit 2009 werden als zusätzliches Instrument aber nicht als Ersatz für österreichische Diplomatie bewertet.

\section{Schlüsselwörter}

Österreich, Diplomatie, EU Außenpolitik, Europäischer Auswärtiger Dienst, EU Delegationen

\section{Acknowledgement}

The author wants to express her appreciation and thanks to Professor Helmut Kramer and Dr. Thomas Nowotny for highly helpful comments and feedback provided on earlier drafts. Also, a big thanks goes to the Austrian diplomats that shared their insights and experience with the author in the framework of qualitative interviews.

The author has declared that no competing interests exist. 


\section{Introduction}

EU membership impacted on Austrian foreign policy. Processes of bottom-up and top-down Europeanisation have been well documented in the academic literature (Wong 20II; Alecu de Fleurs/Müller 20I2), and the contributions to this special issue provide valuable insight in how those mechanisms have played out over time in Austrian development policy (Obvrovsky/Lightfoot in this special issue) and in Austrian membership to regional cooperation (Mueller in this special issue). How Europeanization mechanisms have led to adjustments in Austrian diplomacy, however, has not been subject to comprehensive academic assessment (as empirical exception see Sonnleitner 2015; for more general assessment of member states reaction to European External Action Service see Balfour/Raik 2013).

This contribution discusses how Austrian diplomacy as an instrument of its foreign policy has adapted to changing global, European and domestic contexts. In light of the $2 \mathrm{O}^{\text {th }}$ anniversary of Austrian accession to the European Union, the article puts special emphasis on two particular moments: the impact of EU membership in the last I990s, and secondly the impact of the establishment of the European External Action Service and its delegation network with the Lisbon Treaty since 2009. The impact of EU accession on Austrian foreign policy has been well documented in the literature, and the observations of these contributions also hold true when zooming in on Austrian diplomacy: Austrian diplomats had to get used to the different working mode in the EU negotiating system, while it was the sanctions in 1999 that led to an adapted role definition by Austrian diplomats. It was, however, only in 2009 with the Lisbon Treaty that there was a purposeful attempt to reinvigorate the diplomatic toolset of the European Union and its member states (Vanhoonacker/Pomorska 20I3; Spence/Batora 20I5). It is the impact on Austrian diplomacy of those more current attempts that this paper looks at.

The paper takes the conceptual elaborations of topdown and bottom-up Europeanization from the introduction to this special issue as a starting point, and puts them into the context of wider global pressures and national demands for diplomatic adaptation. Such a widening of the scope proved to be empirically necessary, as not all adjustments in the diplomatic area resulted from the European context. The latter must thus not be mistaken for Europeanisation processes of down-loading or cross-loading. Rather global trends strongly interrelated with European attempts for innovating diplomacy. At the same time, the domestic context of budget cuts and lack of strategic reorientation impeded the Austrian adjustment to the changing global and European context.

Existing literature on Austrian foreign policy (Höll 2002; Kramer 2013a; Kramer 2013b; Kramer/Matzner 2013; Alecu de Fleurs 2012; Sonnleitner 2015) provides useful empirical insights as starting point to assess the changes in Austrian diplomacy. This contribution adds to the existing literature its particular focus on diplomacy as a tool of foreign policy making. It conceptually distinguishes change of diplomacy in terms of content and in terms of institutional set-up, and in line with the overall theme of the special issue, it links the Austrian experience to Europeanisation of small states. Methodologically, the analysis draws on an extensive literature review and makes use of data gathered through primary sources (for example annual Austrian foreign policy reports) and through seven qualitative interviews with Austrian diplomats in Vienna and Brussels in September/December 20I4 and May 2015. In addition, conversations with four academic experts helped the selection of empirical sources and the manner on how to interpret the gathered material.

This contribution looks at changing global, EUlevel and domestic demands and contexts for Austrian diplomacy and the way it has adjusted to these stimuli and pressures. Overall, there was no orchestrated attempt to qualitatively restructure Austrian diplomacy over the past few years. However, in line with global trends, Austrian diplomacy also increasingly focuses on trade promotion and service for citizens, while Austria also participates in smaller attempts for European diplomatic cooperation. In terms of the quality of change, the article shows that Austrian diplomacy is rather adjusting and adapting to pressures steaming from the global and European level instead of taking an active leadership role. However, continuing domestic budget cuts and a lack of perceived political will and strategic vision constrain the possibilities of Austrian diplomacy to fulfil the still global outlook of Austrian foreign policy.

\section{Conceptualising Europeanisation and change of Austrian diplomacy}

Diplomacy is still predominantly perceived as a prerogative of the state, despite increased non-state network activities, new actors and globalisation processes. It is considered an "essentially political activity" in order to pursue "objectives of foreign policies without resort to force, propaganda, or law [.., which...] consists of communication between officials [and includes] such discrete activities as gathering information, clarifying intentions, engendering goodwill" (Berridge 20IO, I). Next to its essential role in bilateral and multilateral negotiations (Nowotny 2011, I2-15), diplomacy is considered a long-term process in order to establish the notion of a close relationship and a common structure for communication between diplomats and different levels of the host country. Diplomacy is not only about single 
actions or reactions at a specific point in time, but about the process of creating a good working relationship and personal contacts.

The introduction of this special issue conceptualises Europeanisation as a process that unfolds through time, which shapes organisational structures, policy process and substance either in a top-down or bottom-up manner (see for example Wong 20II). Whereas Europeanisation research acknowledges the need to understand the comprehensive interaction of various factors such as identities, institutional structures, norms, and changing interests, Europeanization studies often focus on the more narrow distinction between the Europeanisation of foreign policy structures (organisation, routines or procedures) and of foreign policy substance (priorities or objectives).

This distinction of Europeanisation in terms of structures/institutions and substance/objectives is also used in this contribution to structure the empirical analysis according to change of diplomacy in terms of substantive adjustment (content and priorities) and structural adjustment (procedures and institutional set-up) (see first column of table I).

Substantive change of diplomacy takes place when the foreign policy objectives ask for a different aim and content of diplomatic action. By contrast, structural change relates to reforming the available tool-sets as well as the resources and the procedures to apply those tools. The latter can include, for example, the adaptation of the diplomatic network, the re-positioning of embassies vis-a-vis the foreign ministry, or increasing or decreasing the quantity and quality of financial and human resources. Both strands are of course strongly interrelated, if we assume that diplomacy follows a strategic outset and planning. But for analytical clarity they will be considered separately.

In addition, change of diplomacy can take up different modes. It can be passive and unregulated, in a sense that diplomacy is reacting to global developments without political actors actively promoting such a direction. This would resemble a bottom-up approach of actors on the ground integrating new trends in their daily practice, while those changes are not orchestrated actively by the center, i.e. managed by the foreign ministry. On the other hand, political actors can deliberately decide to innovate diplomacy in order to upgrade the diplomatic instruments or to fine-tune diplomatic practice with government priorities. Within the latter, change can be forward-looking, reactive, or opposing. Innovation is deliberative and forward-looking, in that it attempts to assess demands and obstacles of future developments and aligns the diplomatic instruments at one's disposal to these assumed scenarios. Change in diplomacy might be more reactive but still deliberate, in that it takes the form of adaptation to experienced domestic and external pressures. Last, involved actors might deliberately try to reject perceived pressures and show resilience to change.

Next to this conceptualisation of types and modes of changes in Austrian diplomacy, this paper distinguishes between global, European and domestic drivers for change. At the global level, the status, role and tasks of diplomacy have been in flux, while at the domestic level Austrian diplomacy is challenged with continuing financial cuts and the need for changing role conceptions. In addition, the Lisbon Treaty entering into force in 2009 altered and increased European diplomatic cooperation on EU level. It is important to point out that my conceptual framework does not seek to systematically integrate global and domestic drivers of change into the Europeanization framework, but rather presents them as other important drivers that are considered as alternative explanations. Table I provides an overview of the various dimensions and indicators of adjustment in diplomacy that are taken into account.

Table 1: Conceptualisation of change in diplomacy: Levels and indicators

\begin{tabular}{|c|c|c|c|c|}
\hline \multicolumn{5}{|c|}{ Level of Change } \\
\hline & & Global & $E U$ & National \\
\hline \multirow{2}{*}{$\begin{array}{l}\text { Indicator } \\
\text { of Change } \\
\text { of Diplomacy }\end{array}$} & $\begin{array}{l}\text { Substantive } \\
\text { adjustment (what) }\end{array}$ & $\begin{array}{l}\text { - global priorities, } \\
\text { challenges }\end{array}$ & $\begin{array}{l}\text { - to EU priorities and } \\
\text { objectives }\end{array}$ & $\begin{array}{l}\text { - } \text { to new/altered } \\
\text { national priorities }\end{array}$ \\
\hline & $\begin{array}{l}\text { Structural and } \\
\text { Procedural } \\
\text { adjustment (how) }\end{array}$ & $\begin{array}{l}\text { - to new global structures } \\
\text { and processes }\end{array}$ & $\begin{array}{l}\text { - to new EU resources, } \\
\text { structures and } \\
\text { processes }\end{array}$ & $\begin{array}{l}\text { - to domestic resources } \\
\text { structure and processes } \\
\text { (e.g. budgetary cuts, } \\
\text { public service reforms } \\
\text { etc.) }\end{array}$ \\
\hline
\end{tabular}


The levels of diplomatic change are in the following discussed in more detail, before the paper looks empirically of how those trends impacted Austrian diplomacy. We briefly discuss the assumed impact of all three levels global, European, domestic - on diplomacy in a structural and substantive manner.

\subsection{Diplomacy changing in a global context}

Diplomacy has been changing for decades, with an increased non-state actor involvement, multilateralisation, sectoralisation, and the growth of public diplomacy (Duke 2002; Hill/Wallace 1979; Nowotny 20II; for more empirical account on technological impact see Kleiner 2008). It is often superficially assumed that diplomacy and diplomats are in decline as a result of globalization. Hocking, however, convincingly shows that we should not be too quick to conceptualize those changing patterns as decline (Hocking 2004, I47). Rather we should understand those trends as change from hierarchical to network modes: there are now more diverse sets of actors within more complex international interactions (Hocking 2004, I27). There are currently two distinct dynamics pulling diplomacy in contradictory directions: "privatization" with non-state actors taking over many tasks that were considered traditional tasks of public diplomats, and "publicization" with non-governmental actors (private and public) becoming more important as vis-à-vis of diplomats (e.g. increasing strategic public diplomacy). This dichotomy implies that is not any more "top-down, hierarchical models of foreign policy and diplomacy" but that those have been transformed into "dynamic triangular pattern of relations between governments, firms and NGOs" (Hocking 2004, I49, for discussion on network see also Neumann 2012, I72). Diplomats as state representatives continue to play a significant role (Hocking 2004, I27), although their role changes from "gatekeepers" between the domestic and international to "boundary spanners [who are ...] indispensable in managing increasingly complex policy environments through the promotion of communication and trust" (Hocking 2004, 150-15I).

Despite the recent changes in diplomacy, formal representation, information gathering, and communication can still be considered as key tasks of permanent diplomacy (Neumann 2012, 19-20). With 24 hour news cycles, the internet and information available globally, however, the production of knowledge changed for diplomats (Bicchi 20I4): it is not the sole reporting of facts, but the concise analysis of linkages and interdependences of certain events that shape the diplomat's task.

Taking those general considerations into account, we would assume that in terms of substance the task of diplomats in third countries changed towards more network-like activities, by promoting the exchange between Austrian non-state actors and local non-state ac- tors in economic, cultural and social affairs. In addition, with the increased attention for public diplomacy, Austrian diplomats are not only supposed to interact with the government of the host country but also engage with the wider political elite and the public.

\subsection{European membership since 1995 and increased European diplomatic coordination since 2009}

Next to global trends, it is Austrian membership in the EU since 1995 and increased European coordination and cooperation in the Common Foreign and Security Policy (CFSP) that impacts Austrian foreign policy and Austrian diplomacy (see Alecu de Fleurs 2012). In terms of diplomacy, it was the Lisbon Treaty from 2009, which had the most profound impact, what is also the reason why this paper looks especially at the increased diplomatic coordination since 2009. In Brussels, it strengthened the role of the High Representative (HR) who embodies now three roles at the same time: the HR is vice-president of the European Commission, coordinates member states as chair of the Foreign Affairs Council, and is the head of the newly established European External Action Service (EEAS).

The Lisbon Treaty altered EU diplomatic representation: it formally upgraded former European Commission delegations to comprehensive EU delegations and made them part of the European External Action Service (EEAS). EU delegations replaced the rotating Council presidency in representing the Union abroad and coordinating member states on the ground. The latter was achieved by institutionalising regular weekly meetings on counsellor level with member states, and with weekly/monthly meeting of Deputy Chief of Missions and monthly ambassadorial meetings (Maurer/Raik 20I4). The role of the EU delegation thus transformed strongly in the direction of coordinating and providing services for the member states, and to represent the EU once there is a common position.

The Lisbon Treaty tasks the EU delegations thus with representing the Union, not just the Community. While the vagueness in instructions for EU delegations allowed for a variation of practices on the ground, the delegations generally established themselves as hubs in the network of European representation. They provide information and minutes to member states' diplomats, and also circulate minutes to member states without diplomatic representation in the country (Maurer/Raik 20I4).

The idea of establishing a European diplomatic service was a reoccurring theme in the constitutional debate after 2000, although member states considerably disagreed on the shape and power of this new EU body under the leadership of a strengthened High Representative (Morgenstern 2013). The compromise as set in the 
Lisbon Treaty provides a vague definition: the EEAS is a service and not an institution, and the role of the EEAS and its diplomatic network of EU delegations is still subject to various interpretations. While some member states strongly reject the idea of the EEAS taking over any diplomatic tasks from the member states, there are also others who can consider that in the long term a strengthened European cooperation in diplomatic representation could lead member states to shift tasks to the EU delegations instead of operating their own diplomatic representations or to find other forms of synergies in cooperation with other EU member states (EurActiv 20IO). In a first preliminary assessment Balfour and Raik (2OI3) show the variation of how member states react differently to the role of the EEAS in the first few years after the set-up of this new service in Brussels.

In light of Austrian diplomacy, we would assume that in terms of substance Austria aims to use the additional information and analysis shared by EU actors. Structurally, it would be logical that Austria as most small and medium sized member states (see Balfour/Raik 2013 for examples of other EU member states) actively looks for ways of using synergies with other EU member states and the EU delegation.

\subsection{Domestic constraints for diplomatic change}

Pressures for changing diplomacy not only emanate from the global and European environment, but the domestic context must not be ignored. While national foreign ministries are still distinct from sectoral ministries, new public management reforms were also applied in some European countries to innovate diplomacy (e.g. Netherlands). In addition, budgetary pressures since the sovereign debt crisis in 2008 also forced foreign ministries to tighten the belt and look for efficiency savings. Considering the pressures emanating from the domestic context, it can be assumed that structures and procedures are reviewed for efficiency to save costs. Similarly, with limited resources smaller states would substantially increase their strategic focus on particular regions/ topics and align diplomatic efforts even more closely with the top priorities identified by the government.

After specifying the drivers for change in diplomacy on the global, European and domestic level, the next part turns empirically to the case of Austria and investigates how the assumed pressures and trends feature in Austrian diplomacy.

\section{A shift in Austrian diplomacy in the past 20 years? The empirical evidence}

\subsection{Austrian diplomacy keeping up with global trends}

Global trends in diplomacy emphasise increased network activities and public diplomacy efforts. And those current global trends leave their marks also on Austrian diplomacy (see table 2 for overview): the orientation towards citizens increased - towards own citizens through service provision, and towards third country citizens through public diplomacy efforts. Procedurally, the traditional task of information gathering has been replaced by providing concise and timely analysis. In the following those trends are investigated in more detail, focusing first on change in substance and subsequently on procedural change.

In terms of substance, there is an increased attention to orientate Austrian diplomatic efforts towards citizens. The annual Austrian foreign policy reports increasingly highlight the service orientation towards citizens in facilitating safe travel and assisting in emergency situations. This is on the one hand due to the attempt of the

Table 2: Global trends impacting on the substance and processes of Austria

Substantive

What: strategic objectives
Procedural and Structural

How: mechanisms and tools

\begin{tabular}{l|ll}
\hline Global & $\begin{array}{l}\text { Increased service orientation } \\
\text { for citizens } \\
\text { (especially in crisis situations) }\end{array}$ & $\begin{array}{l}\text { Analysis instead of information gathering; } \\
\text { reporting accurate picture outside of } \\
\text { "international cameras" }\end{array}$ \\
& $\begin{array}{l}\text { Despite rhetorically increased service orientation } \\
\text { and public diplomacy, absolute cut in financial } \\
\text { resources for those areas of engagement }\end{array}$ \\
\hline
\end{tabular}


Austria government to provide legitimacy for keeping a global diplomatic network (Interview Brussels, May 2015). On the other hand, the annual Austrian foreign policy report (BMEIA 2OI3, I) explains this increased service orientation through the increased demand for service: the more people travel, the more important it is that the diplomatic network supports its citizens abroad. Thus, the Austrian government installed an electronic travel information registration in 2013 (BMEIA 2013, 30I). Additionally, throughout the annual Austrian foreign policy reports there is a growing emphasis on crisis support. Crisis support teams lead by the Austrian foreign ministry, supported by the defence ministry, have been strengthened in order to be able to speedily react to natural disasters or other emergencies, like for example the hostage taking in Yemen in 2013. ${ }^{\mathrm{I}}$ This service orientation has already been emphasised since 2008 , when the annual report highlights the "increased cooperation of EU member states to exchange information and coordinate" joint evacuation measures (BMEIA 2008, IOI).

This increased orientation towards citizens in Austrian diplomacy extends, however, beyond own nationals towards engaging citizens of third countries. As observed in other diplomatic services, public diplomacy and outreach activities increased. It is especially the cultural activities in positioning Austria as center for the arts, where Austrian diplomats can build on a longstanding tradition. Bringing Austrian artists to a foreign audience and branding those activities as diplomatic promotion for Austria fits smoothly into the new demands of public diplomacy and engaging with a wider circle of recipients than just the host government. The aim behind those activities is clearly defined in diplomatic objectives: "Austria is meant to be presented as modern and innovative-creative country, whose contributions in arts, culture and science are located between tradition and innovation" (BMEIA 20I3, 27I).

Next to this rhetoric, the increased importance of outreach and cultural activities is also reflected in the budget allocation for the heading "cultural activities" within the foreign ministry when compared over a longer period of time: in 1990 only 2.5 million EUR had been allocated, while by 1995 this amount had been increased to 6.5 million EUR (BMEIA 1995, 324, conversion to EUR by author). In 2007 and 2008 more than 7.7 million EUR had been allocated for those cultural activities (BMEIA 2007, 219; BMEIA 2008, 2II), representing stable $2 \%$ of the overall budget for foreign affairs. However, from 2009 onward the allocated resources shrunk successively in absolute and relative terms: were still 6.78 million EUR or $1.6 \%$ allocated to cultural activities in 2009 (BMEIA $2009,244)$, the budget shrunk to 5.64 million EUR or

I See http://www.bmeia.gv.at/en/the-ministry/press/announcements/ 20I3/austrian-hostage-in-yemen-released/
I.3\% in 2014 (BMEIA 20I4, 315). This trend thus clearly reflects an increased discrepancy between rhetorical aims and financial means when it comes to increased orientation towards citizens of Austrian diplomacy.

Procedurally, Austrian diplomacy also follows the global trend for a different kind of diplomatic knowledge production: a stronger emphasis is put on analysis, filtering and interpretation and less on information providing (Interview Vienna, September 20I4). In addition, though, it is also still about getting an accurate picture about the situation on the ground, especially in situations that are not shown in international media. Getting the context right is a crucial task of diplomats when sending their analytical reports back to the capital (Interview Vienna, September 2014). The Austrian diplomat Thomas Nowotny (2OII, I3-I4) confirms this observation. Embassies, for example, are not sole information providers about a host country or hold the monopoly of inter-state communication anymore. He concludes the following:

"The political relevance of embassies has certainly shrunk. Yet, their workload has grown in line with the expansion of trans-border flows of goods and persons. Consulates are even more affected by this heavier workload than embassies. Embassies also retain a certain, politically relevant symbolic function in affirming the political individuality of their home country" (Nowotny 2OII, I4)

Overall, global trends made Austrian diplomacy adapt to those altering demands in a reactive manner. Austria aimed for keeping up with the trend and followed the general way of dealing with those changes, but did not show any resilient or innovating reaction. Similar changes, either in an active or reactive manner, are however also observable in other EU member states. The European dimension with EU membership and increased attempts to coordinate European diplomatic efforts since 2009 had a more profound impact on Austrian diplomacy, as the next chapter will show, although also here changes in Austrian diplomacy were triggered in a bottom-up manner and showed a more reactive style of adaptation.

\subsection{The European dimension: Austria as reactive bot- tom-up adapter}

Two particular events had a considerable impact on Austrian diplomacy: EU accession in 1995, and the EU sanctions against Austria in 1999 (Interview Brussels, May 2015). In the following, we are first going to discuss those events, before turning to the more recent attempts to strengthen European cooperation in diplomacy with the introduction of the European External Action Service. 
Table 3: European trends impacting on the substance and processes of Austrian diplomacy

\begin{tabular}{|c|c|c|}
\hline $\begin{array}{l}\text { Change of Austrian } \\
\text { diplomacy }\end{array}$ & $\begin{array}{l}\text { Substantive } \\
\text { What: strategic objectives }\end{array}$ & $\begin{array}{l}\text { Procedural and Structural } \\
\text { How: mechanisms and tools }\end{array}$ \\
\hline European & $\begin{array}{l}\text { 1995: EU accession: interests despite } \\
\text { neutral status, } \\
\text { 1999: EU sanctions against Austria: } \\
\text { defending and representing interests }\end{array}$ & $\begin{array}{l}\text { - since 1995: a different kind of reporting, } \\
\text { a different kind of constant negotiating } \\
\text { within EU } \\
\text { - } \text { since 2009: Regular meetings of Secretaries } \\
\text { General (twice per year) to discuss cooperation } \\
\text { possibilities; } \\
\text { - co-locations and other attempts to save costs: } \\
\text { pragmatism and bottom-up } \\
\text { - since 2009: COREU and EU delegation network } \\
\text { as useful extra-information tool } \\
\text { - Consular cooperation through “integrated } \\
\text { political crisis response arrangements" }\end{array}$ \\
\hline
\end{tabular}

In terms of type of change, the former had a stronger impact on the substance of Austrian diplomacy, and the change often came in a bottom-up manner from Austrian diplomats rather from political leadership. The latter attempts of increased European cooperation provided impetus for procedural adaptation in a reactive manner (for overview see table 3).

Academic literature (Höll 2002, Alecu de Flers 2012) confirms that EU accession had considerable impact on Austria and Austrian foreign policy. This also holds true for Austrian diplomacy, although two distinctive stages can be observed: right after EU accession Austrian diplomats had to get used to the different way of working in EU negotiations what resulted also in a generational shift in the Austrian diplomatic service. In addition, the increased demand for diplomatic explanation during the EU sanctions reshaped the role conception of a new generation of Austrian diplomats. It was then only with the Lisbon Treaty in 2009 that there were purposive attempts to strengthen European cooperation in diplomatic efforts toward third countries outside of the EU.

In the first months of EU membership, Austrian politicians and diplomats were used to being "neutral" and thus take the middle position in any negotiations. In the particular setting of EU negotiations, however, this was not possible anymore, when different options needed to be considered. The consequence was thus that in its first years Austria often went with the majority, what did not necessarily work well for reflecting own national interests (Interview Brussels, May 2015). This change in attitude was crucial, as diplomats and foreign policy officials considerably had to change their mind-set: being neutral does not mean not having an interest. The new generation of diplomats seemed more apt to define the Austrian position according to interests.

This evolving more interest-driven mind-set of Austrian diplomats was put to the test during the EU sanctions against Austria due to the participation of the right-wing FPÖ in a coalition government with the ÖVP. Suddenly Austrian diplomats had a lot of explaining to do and to defend their country, even if the Austrian government formally provided "an interesting case of stigma rejection" (Adler-Nissen 2014, I60-I62). The subsequent diplomatic sanctions (for more detailed elaboration on this case please check Adler-Nissen 20I4) felt unusual and challenging to Austrian diplomats, as since 1955 Austrian diplomats never experienced the feeling to have "direct enemies" (Interview Brussels, May 2015). Austrian diplomats had to provide the link to the host country, enhance good will, and receive goodwill back. Austria branded itself successfully by providing special expertise in certain geographical and thematic issues and with hosting international negotiations, especially during the Cold War period. During the EU sanctions now suddenly explanations were on order, and most Austrian diplomats were caught speechless in a situation that was perceived as unusual. But after the first shock of discomfort, there was also an added value for the diplomatic service: diplomats increasingly felt a purpose in defending Austrian reputation and offer explanations. And with this strengthened mind-set in place it also became normal to defend Austrian interests abroad. Again, not all diplomats felt comfortable in supporting this change in diplomatic practice, what marked another generational turnover in the diplomatic service. 
Strengthening European diplomatic cooperation was a main objective of the constitutional draft negotiations and the Lisbon Treaty in 2009. The role of the High Representative was strengthened and fulfilled now also the role as Vice-President of the European Commission, the chair of the Foreign Affairs Council, and head of the newly established European External Action Service (Vanhoonacker/Pomorska 20I3). Outside of Brussels, the aim was to increase European cooperation in diplomatic activities by upgrading former Commission delegations to EU delegations, which reinvigorated the role previously preformed by Council presidencies to coordinate member states diplomats in third countries (Maurer/Raik 20I4).

Austria like most member states carefully observed the set-up of the European External Action Service, whose institutional status has been kept vague in the treaty text. Member states were not necessarily negative towards this innovation, but it was not totally clear from the outset how this service would work in practice and how it would relate to the diplomatic services of the member states. Only from 20II onwards the new setting became more concrete, as the following account of Austria shows.

In the first few years after the Lisbon Treaty there is a vague mentioning of the EEAS and its delegations in the annual Austrian foreign policy report. The 2008 report (BMEIA 2008, 8-IO) explains in detail the ratification process of the Lisbon treaty in Austria and other EU member states, while the 2009 one for the first time explicitly mentions the EEAS: this service "is going to combine the foreign policy tools of the member states and the resources of the EU institutions" (BMEIA 2009, 9). The 2010 edition (BMEIA 20IO, I4-I5) explains the first steps in the Lisbon Treaty implementation and provides a short explanation of how the new service and its delegations are going to look like.

The very detailed elaboration of over two pages in the annual Austrian foreign policy report in $201 \mathrm{I}$ reflects the formal adoption of the Council decision to establish the EEAS in December 20IO. Next to a concise overview of the structure and set-up of the EEAS, the 2ori report also provides a concise reasoning of the Austrian support for the EEAS:

"Austria supports the establishment of the EEAS, because the EEAS provides more coherence and stronger vigor to the Common Foreign and Security Policy (CFSP), to which Austria is actively contributing. The role and influence of the $E U$ as an international actor is thus strengthened in a considerable and sustainable manner. At the same time, Austria is now in the position to represent its foreign and security interests not only bilaterally, but it can do so also through the EEAS in a more efficient and successful manner." (BMEIA 2OII, 37)
In a similar manner, the relationship between the EEAS and the diplomatic services is concisely reflected upon and shows clear expectations towards the added value of this new service:

"The Lisbon Treaty does not constrain member states competences in the formulation and implementation of their foreign policies or of their diplomatic representations in third countries or towards international organisations. The tasks and functions of the Austrian foreign ministry do therefore not change due to the EEAS. The Austrian foreign ministry, however, works in close cooperation with the EEAS and thus ensures that Austria contributes to the foreign policy action of the EU and of the CFSP in particular" (BMEIA 2OII, 38; translation by author).

The Austrian support for the EEAS and its emphasis that the EEAS is an additional tool rather than a substitute for Austrian diplomatic action is also reiterated in the annual Austrian foreign policy reports of 2012 (BMEIA 20I2, 29) and 20I3 (BMEIA 2OI3, 29-2I). In those reports Austria furthermore reconfirms that there has not been a substantial increase in personnel for the EEAS despite their additional roles in coordination and chairing. This move is explicitly explained as to ensure that the EEAS does not duplicate activities of EU member states embassies in third countries (BMEIA 2013, 19).

Staffing is a reoccurring salient aspect for Austrian diplomacy but also for the EEAS. In 20I4, $320 \mathrm{Mem}-$ ber states diplomats of a total of 945 staff (AD officials) worked for the EEAS (EEAS 2015, 55-57). In total there were 27 Austrians: in the headquarters in Brussels Io Austrian are employed as officials, while 3 work as temporary agents. In the delegations there are 7 officials as well as 7 temporary agents. Io of those 27 Austrians are assigned as member states diplomats, while the other I7 Austrians are employed directly as EEAS staff (EEAS 20I5, 57). From the Austrian diplomatic service, so far II diplomats applied for a temporary assignment with the EEAS, whereas disregarding the official affiliation a total of 43 Austrians work in the EEAS, among which several EU ambassadors (BMEIA 2OI3, 19).

Seconded Austrian diplomats so far do not experience any direct disadvantage in their diplomatic career, although expectations need to be managed to avoid disappointment upon return: within the Austrian diplomatic service it is difficult to offer the same high ranking posts like seconded Austrian diplomats can be assigned for in the EEAS (Interview Vienna, September 2014). At the onset of the EEAS there was some general fear with member states that "best diplomats will move to the EEAS" (EurActiv 20I0), and indeed for smaller and medium-sized diplomatic services the negative shortterm impact of sending staff to the EEAS for 3-4 years is considered in their choice of seconding diplomats to the 
EEAS (interview Vienna, September 20I4). Since 2009, Secretaries General of EU member states meet twice per year with the EEAS in order to discuss future cooperation possibilities and synergies (Interview Vienna, September 20I4).

Next to those procedural aspects directly related to the EEAS, increased attempts to coordinate European diplomatic action triggered additional procedural impact: the COREU network for extra-information and colocations for cost efficiency. In the post-Lisbon Treaty situation, the Austrian foreign ministry now also receives reports through the COREU network from countries where it has no diplomatic representation. Those reports are either issued by the EU delegation or the substituting member state and contain regular assessments of the situation on the ground. It is "a nice added aspect" (Interview Vienna, September 20I4), although the added value for Austrian diplomacy must not be overestimated: if Austria would have an interest in the particular country, it would have a diplomatic representation there.

The second re-occurring issue on European diplomatic coordination during the past two years is the opportunity for co-locations and other attempts to create synergies (BMEIA 20I3, 300). The EEAS aims at supporting member states efforts in this regard through creating a platform (Interview EEAS, January 2014), although it is mostly member states who push this debate like the German foreign ministry in September 2014 (interview Vienna, September 2014). In the Austrian context, attempts for co-locations are nothing new, as already foreign minister Plassnik between 2005-9 experimented in cooperation with Hungary and Switzerland. Co-locations can work well when it is with countries that have similar security standards, but very often it is a pragmatic discussion about locations, venues, and technical possibilities, which can vary greatly from third country to third country (Interview Vienna, September 20I4). In the public (Euractiv 20IO) and expert discourse (Austrian Court of Auditors 2014, 198-199) such forms of European cooperation are often heralded as a great future tool to safe costs, but so far a pragmatic and adhoc approach was the rule, and it has to be seen to what extent the EEAS and member states exchanges on the EU level can support the development of joint locations.

The third major topic of increased European cooperation refers to consular cooperation and the establishment of "integrated political crisis response arrangements". While the general discussion is still vague, it is in crisis situations where member states and also Austria see potential for increased cooperation. The annual Austrian foreign policy report states that "the role of the European External Action Service in terms of supporting member states in their dealings with consular crisis relevant activities should be examined more closely"
(BMEIA 20I3, 2). For now, EU member states established the EU Integrated Political Crisis Response arrangements (IPCR) in 20I3, which is meant to support a quick coordination of member states during disasters, attacks or other major emergency situations. ${ }^{2}$

EU membership in 1995 and the increased attempts for increasing European diplomatic cooperation since 2009 considerably impacted Austrian diplomacy. In terms of substance, EU accession and especially EU sanctions in 1999 changed the mind-set of Austrian diplomats by moving towards a stronger interest representation despite neutrality. Procedurally, Austrian diplomacy adapted to the EU way of negotiating and Austria generally supported the establishment of the EEAS as an additional tool to represent its interests globally. Both strands feature a strong reactive adaptation of change in diplomacy. In the following, we are going to now also consider the domestic context, which can of course not be ignored when considering change of Austrian diplomacy.

\subsection{The domestic dimension not to be ignored: Aus- trian diplomacy just as good as Austrian foreign policy makers want it to be}

The domestic discourse on Austrian diplomacy during the past decade has been predominantly informed by governmental budget cuts. Despite fewer resources there was no adaptation of the global outlook in foreign policy strategy, and after 2008 the political elite seemed to have lost any interest in foreign policy or diplomacy as a tool (see contribution by Helmut Kramer in this special issue for a more detailed account of Austrian foreign policy and its renationalisation and provincialisation). With foreign minister Kurz coming into office in December 2013 the political attention for foreign affairs has been growing again, although messages are mixed, and the discrepancy between the global ambitions of Austrian foreign policy and the shortage of means remains (see table 4 for overview). Next to the need for political steering in setting clear foreign policy objectives (substantive dimension), diplomacy as a tool of foreign policy even after technological innovations is still resource intense and highly dependent on man-power and financial resources (procedural dimension).

In terms of tools and available resources, Austrian diplomacy has been considerably constrained by cuts. Especially for diplomatic tools, resources and manpower are still key and directly dependent on available financial means. After EU accession the Austrian government focused on achieving the Maastricht criteria for the third stage of the Euro, which was supported by

2 For details see http://www.consilium.europa.eu/en/documents-publications/publications/2OI4/eu-ipcr/ 
Table 4: Domestic issues impacting on the substance and processes of Austrian diplomacy

\begin{tabular}{l|ll}
\hline $\begin{array}{l}\text { Change of Austrian } \\
\text { diplomacy }\end{array}$ & \multicolumn{1}{l}{$\begin{array}{l}\text { Substantive } \\
\text { What: strategic objectives and strategy }\end{array}$} & $\begin{array}{l}\text { Procedural and Structural } \\
\text { How: mechanisms and tools }\end{array}$ \\
\hline Domestic & $\begin{array}{l}\text { Add-ons (FM Kurz): service orientation } \\
\text { and business support }\end{array}$ & $\begin{array}{l}\text { Several phases of budget cuts and "fiscal } \\
\text { consolidation": "do the same with less resources" } \\
\text { No strategic reorientation in geographical } \\
\text { and thematic coverage - cover it all; }\end{array}$ \\
\hline
\end{tabular}

a generally positive growth of the Austrian economy. However, in 1999, it was the ÖVP-FPÖ coalition that introduced budget cuts and structural consolidation through savings on expenses as main focus of government reforms ${ }^{3}$. In 2000, EUR 327 million were allocated for external affairs in the Austrian budget (0.56\% of total federal expenses). This amount decreased to EUR 301 million and $0.49 \%$ in 2003 , before increasing steadily to EUR 4I5 million in 2008 (0.52\% of Austrian budget). With the exceptions of 2010 and 2OII (EUR 43I and 427 million respectively), the external affairs budget sank again towards EUR 417 million in 2015 (0.48\% of total national expenses) $)^{4}$. Although cross-national comparisons are difficult due to different allocations of areas under the heading "external spending, it is quite telling that Germany, for example, spent I.I4\% of its federal budget on foreign affairs in $2014^{5}$.

The Austrian diplomatic service had accepted the imposed cuts and tried to show that it "can cut costs better" (Interview Brussels, May 2015) than other ministries. But because the Austrian diplomatic service had started off with a quite stretched staffing level already, those cuts form 2000 onwards led to a "chronic understaffing", especially compared to diplomatic services of similarly sized countries. In the Austrian permanent representation in Brussels, for example, there are Io diplomats working on foreign affairs, while Sweden has up to 30 diplomats at their disposal. This understaffing and underfinancing thus shows especially in terms of available staff. Kramer/Matzner (2013) show tellingly that the already quite thin account of 1600 staff in 1995 shrank to I200 staff in 2013, while the necessity for international presence and the increased consular work for traveling citizens grew. At the same time the diplomatic network hardly changed during the past 20 years (see table 5).

3 See parliamentary discussion on budget report 1999 for more details: http://www.parlament.gv.at/PAKT/PR/JAHR_200o/PKo279/ index.shtml

4 Data taken from from Budget act 20I2, budget act 20I4, and from the Austrian budgetary report 2014/2015: https:/www.bmf.gv.at/ budget/das-budget/Budgetbericht_2OI4_20I5.pdf?4jwmo9

5 http://dip2r.bundestag.de/dip2I/btd/18/020/I80200o.pdf
Table 5: Austrian diplomatic representation 1995 and 2013 compared (Data taken from BMEIA 1995, 2008 and 2013)

\begin{tabular}{lrrr}
\hline & 1995 & 2008 & 2013 \\
\hline Bilateral Embassies & 80 & 81 & 80 \\
\hline Representation at IOs & 7 & 5 & 5 \\
\hline General Consulates & 18 & 14 & 8 \\
\hline Independent cultural fora & 11 & 6 & 6 \\
\hline Different representative body & & 1 & 1 \\
\hline
\end{tabular}

In order to keep the diplomatic network despite the fewer available resources, this meant of course that staff was reduced per posting. Many postings were cut down to one diplomat plus one additional staff member, what is enough to receive reports from those locations but does not leave any resources for additional activities (Interview Brussels, May 2015). While the Austrian foreign service tried to make ends meet while still achieving the same objectives, the Austrian court of auditors in its 2014 special report emphasises that "structural changes did not follow any strategic planning documentation" (Austrian Court of Auditors 2014, 190).

The Austrian foreign affairs budget already started from a very low level in 2000, and even more so it is necessary to note that with Sebastian Kurz taking up the office as foreign minister in December 2013 the agenda for "improvement of integration" has been moved into the foreign ministry and thus also into the budget for foreign affairs. The 2015 foreign affairs budget of EUR 417 million thus allocates EUR 249 million to operational issues, of which EUR 76 million are for the foreign ministry and EUR 173 million for the embassy network. The additional EUR I68 million are comprised of EUR 22 million for improvement of integration, EUR 65 million for development cooperation, and EUR 80 million for contributions to international organisations (Austrian Budget Act 2015, I25-131).

This structural shortcoming in terms of Austrian diplomacy, is also directly linked to the lack of a clear 
substantive re-focusing of Austrian diplomacy. The problem is that time and again "there were cuts but not savings" in the Austrian foreign policy budget (Interview Vienna, September 20I4). Cuts imply simply less financial means by doing the same, while savings would be accompanied by a strategic reconsideration of longterm effects. This strategic re-orientation, however, has not taken place, and quite on the contrary the Austrian foreign and diplomatic service is now meant to cover even additional areas and services. The Austrian Budget Act 2014 explains the need for increased service for citizens as following:

"The motto 'globally there for you' reflects the selfimage about expected outputs and the increasing expectations of our citizens. [...] The fact that Austrians in a globalised world are getting more mobile constantly increases consular work and the necessity of consular presence. Austrians take approx. Io million trips abroad peryear; more than 450.000 citizens stay abroad for a considerable amount of time. More and more Austrians are subject to crisis or catastrophe scenarios abroad" (Austrian Budget Act 2014, I2O).

This emphasis on the increased service orientation of Austrian diplomacy (also confirmed in BMEIA 2OI3) strongly reflects the publicly announced strategic reorientation by current foreign minister Kurz, who next to citizens service also pinpointed service for investment promotion and additional support for Austrian business as additional tasks for Austria diplomacy (Interview Vienna, September 20I4). Critical voices though keep emphasising that adding those additional tasks does still not provide a strategic outlook for Austrian diplomacy. Despite EU accession and continuous budget cuts, and despite Austria being a small state with limited resources there is still an attempt to cover everything. The Austrian diplomatic service certainly provides special expertise in key areas like the Balkans or Eastern Europe, but there is no strategic prioritisation (Interview Brussels, May 2015; for similar critical remarks see Kramer 20I3a). Since 2008 observers increasingly lament a "tendency toward 'inward-politicisation' and 'tabloidization' of foreign policy decisions" (Kramer 20I3b, see also Kramer in this special issue). This lack of political steering is not only harming the reputation of Austrian diplomacy, but it also does not fulfil the need for active diplomatic efforts due to Austria's neutral status.

\section{Concluding Remarks}

This contribution analysed how Austrian diplomacy has adapted to changing global, European and domestic conditions since Austrian accession to the EU in 1995. In terms of quality of change, Austrian diplomacy mostly is characterised by reactive adaptation, while especially the impact of EU accession and EU sanctions in 1999 followed bottom-up dynamics that were triggered by individual diplomats rather than top-down strategic steering by political decision-makers.

Austria generally followed the global trend by increased service orientation for citizens and additional attention on trade and investment promotion in Austrian diplomacy. On domestic level the drivers of change are quite stable since 2000: repeated budget cuts and efficiency measures are at the core of domestic impact, while the diplomatic network has been kept the same size. Overall despite this permanent shortage of resources there has been no strategic reorientation. Quite on the contrary the tasks of Austrian diplomacy have been even extended.

In regard of the European dimension and the focus of this special issue, Austria again plays along and shows a rather reactive attitude. The Austrian diplomatic service is pleased with the extra information received from EU delegations and member states coordination on the ground in third countries without overestimating its added value. At the same time, they also clearly indicate that the EEAS is to be seen as an additional tool for Austrian interest representation rather than a substitute for Austrian diplomacy and Austrian foreign policy making. In comparison, the socialisation of Austrian diplomats after EU membership and the change in mind-set after the EU sanctions in 1999 had a more long-lasting impact on Austrian diplomacy. EU membership had a considerable impact on Austrian diplomacy, although this paper also showed that diplomatic adjustments cannot be fully understood without also taking into account the domestic and global contexts.

\section{Literature}

Adler-Nissen, Rebecca (20I4). Stigma Management in International Relations: Transgressive Identities, Norms, and Order in International Society, in: International Organization, Vol. 68(I), I 43-I76.

Alecu de Flers, Nicole (2012). EU Foreign Policy and the Europeanization of Neutral States: Comparing Irish and Austrian Foreign Policy, London/New York.

Alecu de Flers, Nicole/Patrick Müller (2012). Dimensions and Mechanisms of the Europeanization of Member State Foreign Policy: State of the Art and New Research Avenues. in: Journal of European Integration, Vol. 34(I), I9-35.,

Austrian Budget Act (2015). [Bundesfinanzgesetz 2015]. Internet:https://service.bmf.gv.at/BUDGET/Budgets/ 20I4_2015/bfg2015/Bundesfinanzgesetz_2015.pdf (accessed: 13.10.2015) 
Austrian Court of Auditors (2014). Structure of Austrian diplomatic representation within the European Union. Report of the Austrian Court of Auditors 20I4/8. Internet: http://www.rechnungshof.gv.at/ fileadmin/downloads/_jahre/20I4/berichte/teilberichte/bund/Bund_2OI4_08/Bund_2OI4_08_3. pdf (accessed: I3.10.2015)

Balfour, Rosa/Kristi Raik (20I3). The European External Action Service and National Diplomacies. European Policy Center Issue Paper No. 73. European Policy Center. Internet: http://www.epc.eu/documents/ uploads/pub_3385_the_eeas_and_national_ diplomacies.pdf (accessed: 24.04.2016)

Bátora, Jozef (2005). Does the European Union transform the institution of diplomacy?, in: Journal of European Public Policy, Vol. I2(I), 44-66.

Bátora, Jozef/Brian Hocking (2009). EU-oriented bilateralism: evaluating the role of member state embassies in the European Union, in: Cambridge Review of International Affairs, Vol. 22(I), I63-I82.

Berridge, Geoff R. (2010). Diplomacy. Theory and Practice. 4 th ed, Basingstoke/New York.

Bicchi, Federica (20I4). Information exchanges, diplomatic networks and the construction of European knowledge in European Union foreign policy, in: Cooperation and Conflict, Vol. 49(2), 239-259.

BMEIA (1995). Austrian Annual Foreign Policy Report 1995. Internet: http://diglib.uibk.ac.at/ulbtirol/ periodical/pageview/155753?query=aussenpolitisch er\%20bericht\%201995 (accessed: 24.04.2016)

BMEIA (2008). Austrian Annual Foreign Policy Report 2008. Internet (https://www.bmeia.gv.at/fileadmin/ user_upload/Zentrale/Publikationen/AEPB/ Aussenpolitischer_Bericht_2009.pdf (accessed: 24.04.2016)

BMEIA (2009). Austrian Annual Foreign Policy Report 2009. Internet: https:/www.bmeia.gv.at/fileadmin/ user_upload/Zentrale/Publikationen/AEPB/ Aussenpolitischer_Bericht_2009.pdf (accessed: 24.04.2016)

BMEIA (20I0). Austrian Annual Foreign and European Policy Report 20IO. Internet: https://www.bmeia.gv.at /fileadmin/user_upload/Zentrale/Publikationen/ AEPB/Aussen-_und_Europapolitischer_Bericht 20IO_2.pdf (accessed: 24.04.2016)

BMEIA (2OII). Austrian Annual Foreign and European Policy Report 20II. Internet: https://www. bmeia.gv.at/fileadmin/user_upload/Zentrale/ Publikationen/AEPB/Aussen-_und_Europapolitischer_Bericht_20II.pdf (accessed on 24.04.2016)

BMEIA (2012). Austrian Annual Foreign and European Policy Report 2012. Internet: https://www. bmeia.gv.at/fileadmin/user_upload/Zentrale/ Publikationen/AEPB/Aussen_und_Europapolitischer_Bericht_2OI2.pdf (accessed: 24.04.2016)
BMEIA (20I3). Austrian Annual Foreign and European Policy Report 2013. Internet: https://www. bmeia.gv.at/fileadmin/user_upload/Zentrale/ Publikationen/AEPB/Aussen_und_Europapolitischer_Bericht_20I3.pdf (accessed: 24.04.2016)

Duke, Simon (2002). Preparing for a European Diplomacy?, in: Journal of Common Market Studies, Vol. 4O(5), 849-70.

EEAS (2015). Human Resource Report of the European External Action Service 20I4. Internet: http://eeas. europa.eu/background/docs/hr_report_2OI4_final_ en.pdf (accessed: 24.04.2016)

EurActiv (2010). EAD: Top-Diplomaten und "Laptop"Botschafter. Published 23 October 20IO. Internet: http://www.euractiv.de/europe-2020-und-reformen/artikel/ead-top-diplomaten-undlaptop-botschafter-003282. (accessed: 24.04.2016)

Hill, Chris/William Wallace (1979). Diplomatic Trends in the European Community, in: International Affairs Vol. 55(I), 47-66.

Hocking, Brian (2004). Privatizing Diplomacy? ISP polity forum: the privatization of diplomacy and security, in: International Studies Perspectives, Vol. 5, I47-I52.

Höll, Otmar (2002). Außen- und Sicherheitspolitik, in: Heinrich Neisser/Sonja Puntscher-Rieckmann, (eds.): ,Europäisierung' der Österreichischen Politik? Konsequenzen der EU-Mitgliedschaft, Vienna, 369-395.

Kleiner, Jürgen (2008). The Inertia of Diplomacy, in: Diplomacy and Statecraft, Vol. 19, 32 I-349.

Kramer, Helmut (2013a). Österreichs Beitrag zur europäischen und globalen Sicherheit. Ein Plädoyer für mehr Selbstbewusstsein im Bekenntnis zu aktiver Neutralitäts- und Friedenspolitik, in: Thomas Roithner/Johann Frank/Eva Huber (Hg), Wieviel Sicherheit braucht der Friede? Wien.

Kramer, Helmut (20I3b). Bleibt Österreichs Außenpolitik eine "Draussenpolitik"?, in: International, Vol. 4, 4550.

Kramer, Helmut/Gabriele Matzner (2013). Österreichs Außenpolitik: Planung tut bitter not. Der Standard 27 December 2013. Internet: http://derstandard. at/I385172257325/Oesterreichs-AussenpolitikPlanung-tut-bitter-not (accessed on 24.04.2016)

Maurer, Heidi/Kristi Raik (2014). Pioneers of a European Diplomatic System: EU Delegations in Moscow and Washington. Finnish Institute of International Affairs (FIIA) Analysis Brief No. I. Internet: http:// www.fiia.fi/en/publication/4I5/pioneers_of_a european_diplomatic_syste/ (accessed: 24.04.2016)

Morgenstern, Jost-Henrik (2013). The shape of things to come: historical institutionalism and the origin of the European External Action Service. Paper presented at the 43rd UACES Annual Conference, Leeds. 
Neumann, Iver B. (2012). At Home with the Diplomats: Inside A European Foreign Ministry, New York.

Nowotny, Thomas (201I). Diplomacy and Global Governance. The Diplomatic Service in an Age of Worldwide Interdependence, New York.

Sonnleitner, Sandra (2015). Austrian Bilateral Diplomacy in the Context of EU Membership: Case Study on the Austrian Ministry of Foreign Affairs, EUFORPOL Working papers $\mathrm{WP} 7 / 2015$. Internet: http://staryweb. fses.uniba.sk/fileadmin/user_upload/editors/ UESMV/EUFORPOL/EUFORPOL_WP7_SandraSon. pdf (accessed: 24.04.2016).

Spence, David/Jozef Batora (eds.) (2015). The European External Action Service: European Diplomacy PostWestphalia, London.

Vanhoonacker, Sophie/Karolina Pomorska (2013). The European External Action Service and agendasetting in European foreign policy, in: Journal of European Public Policy, Vol. 2O(9), I3I6-I33I.

\section{Author}

Dr. Heidi Maurer is Assistant Professor in European Union Foreign Policy Making at the Faculty of Arts and Social Sciences at Maastricht University. In 2012/13 she was the Austrian Marshall Plan Foundation Fellow at the Centre for Transatlantic Relations (CTR) at the School for Advanced International Studies (SAIS) at Johns Hopkins University in Washington DC. Her research interest focuses on EU foreign policy-making, European diplomacy, and the European Neighbourhood Policy. Since joining Maastricht University, Heidi also engages actively in research about alternative teaching methods and in particular Problem-Based Learning. 
